\title{
Economic Strategies, Community, and Food Networks in Ulukhaktok, Northwest Territories, Canada
}

\author{
PETER COLLINGS
}

(Received 1 June 2009; accepted in revised form 13 October 2010)

\begin{abstract}
This paper examines the social networks of country food sharing in Ulukhaktok, Northwest Territories, Canada, in light of our current understanding of the relationship between climate change and Arctic peoples. Most recent work on the impacts of climate change on Arctic peoples has tended to focus on conceptual frameworks appropriate for this field of inquiry or to document perceived threats of climate change. This research incorporates a social network approach to document the association between different economic strategies (full-time worker, part-time worker, hunter) and categories of kin. It demonstrates that the sharing patterns of hunters favor the cultivation of ties with distant and collateral kin, while those of wage earners favor ties with parents and siblings. These different affiliations point to different vulnerabilities to change. For example, hunters pursue a strategy that provides the flexibility and connections necessary for adapting to changing environmental circumstances but increases their vulnerability to economic and political changes that restrict their ability to generate cash. Wage workers, despite a steady income, are more vulnerable to environmental change as it affects traveling conditions, potential hazards, and hunting success.
\end{abstract}

Key words: Inuit, Canada, climate change, social networks, subsistence, food sharing

RÉSUMÉ. Dans ce document, nous nous penchons sur les réseaux sociaux en matière de partage de la nourriture de campagne à Ulukhaktok, dans les Territoires du Nord-Ouest, au Canada et ce, à la lumière de notre compréhension actuelle de la relation qui existe entre le changement climatique et les peuples de l'Arctique. Les travaux les plus récents relatifs aux incidences du changement climatique sur les peuples de l'Arctique avaient tendance à se concentrer sur les cadres conceptuels convenant à ce domaine d'enquête ou sur les menaces perçues du changement climatique. Pour sa part, la présente recherche a recours au réseau social pour cerner le lien qui existe entre les différentes stratégies économiques (travailleur à plein temps, travailleur à temps partiel, chasseur) et les catégories de parenté. Nous démontrons que les modèles de partage des chasseurs favorisent la culture de liens avec la parenté distante et la parenté en ligne collatérale, tandis que les salariés favorisent les liens avec les parents, les frères et les sœurs. Ces affiliations différentes laissent entrevoir des vulnérabilités vis-à-vis du changement. Par exemple, les chasseurs adhèrent à une stratégie qui leur donne la souplesse et les liens nécessaires pour s'adapter aux circonstances environnementales changeantes, mais qui accroît leur vulnérabilité en matière de changements d'ordre économique et politique, changements qui restreignent leur aptitude à faire de l'argent. Pour leur part, les salariés, malgré leur revenu stable, sont plus vulnérables au changement environnemental dans la mesure où il a des incidences sur les conditions de déplacement, les risques éventuels et le succès à la chasse.

Mots clés : Inuit, Canada, changement climatique, réseaux sociaux, subsistance, partage de nourriture

Traduit pour la revue Arctic par Nicole Giguère.

\section{INTRODUCTION}

The human dimensions of climate change in the Arctic have become an increasingly important and urgent research focus for both social and natural scientists. Although a large body of research addressing climate change in the Arctic has emerged, work that specifically examines the perceived and potential impacts of climate change on people is relatively recent. Currently, the primary concerns of social scientists are to document the links between changes in the climate and their possible impacts on human cultural and economic survival. Economic survival in northern economies is threatened by changes in the availability of the wildlife that hunters depend on for their subsistence. Cultural survival is threatened not only by economic changes, but also by disruptions to social structure, cultural practices related to subsistence, and the continued viability of traditional knowledge (Peterson and Johnson, 1995; Cohen, 1997; Krupnik and Jolly, 2002).

The prevailing paradigm that shapes our understanding of climate change as it affects people tends to follow frameworks developed by examining human-climate interactions from ecological and systemic perspectives in research on ecology (Gunderson et al., 1995; Gunderson, 2000, 2002; Gunderson and Holling, 2002; Berkes et al., 2003) and hazards and vulnerability (see Kelly and Adger, 2000;

${ }^{1}$ Department of Anthropology, PO Box 117305, University of Florida, Gainesville, Florida 32611, USA; pcollings@ufl.edu

(C) The Arctic Institute of North America 
McCarthy and Martello, 2005). Concepts derived from ecological theory, such as adaptability, resilience, and vulnerability, have often been applied directly to human cultural systems, and often humans are treated as an embedded component of a larger ecological system. Approaches incorporating indigenous perspectives have tended to focus either on documenting indigenous perceptions of climate-change effects or on recording the potential threats to people from climate change. Little research has focused on specific mechanisms and processes of change, however, or on the relationship between climate change and the constellation of secular changes that northern residents have experienced over at least the last half-century (but see Berman and Kofinas, 2004; Berman et al., 2004; Brinkman et al., 2007).

The present paper examines the social networks of country food sharing in Ulukhaktok, Northwest Territories, Canada, within the context of our current understanding of the relationship between climate change and Arctic peoples. In particular, I focus on ethnographic approaches to understanding climate change using a network analysis of food sharing patterns, affiliations with kin, and economic strategies used by Inuit men. My approach therefore builds on prior research by focusing as much on what people do in the context of changing conditions as on what they say about climate change. The paper addresses two specific concepts used in research about people and climate change: соттиnity and adaptability.

The term "community" is commonly used to refer to Arctic settlements as both spatial and cultural entities. The community in this sense is frequently used as the unit of analysis, and it is further assumed to be capable of adapting to changing circumstances. Using the settlement of Ulukhaktok as an example, this paper argues that while Arctic villages may be communities in a spatial sense, they are frequently composed of several cultural entities that may or may not be disposed to act in concert with each other. In what follows, I use the term "settlement" to refer to the spatial notions implied in the term "community," while using the term "community" to refer to the notion of a cohesive social group.

The term "adaptability" is defined here as the potential for a group to act collectively in the face of rapidly changing environmental circumstances (following Crate, 2008). Although adaptability is often treated across different scales, in this paper I limit my treatment of the adaptive capacity of a settlement such as Ulukhaktok by examining individual economic strategies pursued by individuals within the settlement. In particular, I focus attention on the connections between different economic strategies and how these strategies map onto particular kinds of affiliations with kinship connections in the settlement.

\section{THEORETICAL \& ETHNOGRAPHIC BACKGROUND}

Despite increasing attention paid to climate change and the effects of those changes on Arctic ecosystems, the impact of climate change on the people who live in the Arctic and Subarctic has been vastly understudied (Nuttall, 2004). Only in the past decade has research begun to focus on the human dimensions of climate change in the Arctic.

The relative youth of this research domain naturally means that our knowledge is still quite limited. Indeed, a significant body of literature specifically focuses on developing conceptual approaches to this problem. In Arctic work, the focus on climate change is largely concerned with applying concepts like adaptive capacity, resilience, transformability, and vulnerability to ecological systems in which humans are significantly involved (Ford and Smit, 2004; Robards and Alessa, 2004; Smit and Wandel, 2006). More specific investigations have documented the impacts of ecosystem changes on Native communities, focusing on one of three domains. Research focusing on climate change and subsistence has outlined the potential for increased risk associated with mechanized foraging in rapidly changing physical environments (Ford et al., 2006a, b; Furgal and Seguin, 2006; Tremblay et al., 2006). Studies of wildlife have documented changes in the availability and health of resources upon which Native peoples depend for their subsistence (Riedlinger and Berkes, 2001; Whiting, 2002; Stirling and Smith, 2004; Brinkman et al., 2007). Other studies have recorded local perceptions and observations of climate change and discussed their potential impacts (Berkes and Jolly, 2001; Riedlinger and Berkes, 2001; Fox, 2002; Jolly et al., 2002; Ford and Smit, 2004; Huntington and Fox, 2005). Much of the work cited here expresses concerns about future prospects for cultural survival, and nearly all of it contains clear implications for policymaking and governance.

Despite the utility of this research in documenting the problem of climate change for people living in the Arctic, the processes of change in Arctic communities have received little attention. Adaptability and adaptation, after all, are processes rather than static states (Ulijaszek, 1997). What are the mechanisms by which changes associated with climate affect people? Two distinct approaches characterize the work that underlies our current understanding of how climate change affects people in the Arctic. The first approach is methodological: most of this work relies on informant self-reports, focus groups, and semi-structured or unstructured interviews. The second approach is conceptual, relying on the community as the unit of analysis, typically as a case study of climate change impacts on people. I take a somewhat different methodological and conceptual approach to investigating climate change and adaptability in the Arctic, examining the problem of climate change inductively, working from ethnographic data to better understand the applicability of concepts and methods as they pertain to the problem of climate change.

Community vs. Settlement as an Analytical Unit: Ulukhaktok as an Example

Ulukhaktok (formerly Holman, or Holman Island) is a small, primarily Inuit settlement on Victoria Island in the 
Northwest Territories. The settlement (population ca. 430) has been the site and subject of a good deal of social science research on several topics over the last two decades. Significant work has been done on life course development (Condon, 1987, 1988, 1990a, b; Collings, 2000, 2001), and other topics include culture change (Condon, 1991, 1992, 1994; Collings, 2005) and subsistence and land use (Usher, 1965; Smith and Wright, 1989; Condon et al., 1995; Collings, 1997; Collings et al., 1998; Collignon, 2006). More recent investigations in Ulukhaktok have examined the impacts of climate change on settlement residents (Pearce et al., 2006, 2009, 2010; Ford et al., 2008).

I am deliberately using the term "settlement" to refer to Ulukhaktok rather than the more common term "community." Most researchers conflate the two terms (Wenzel, 2008), using them interchangeably, and seem to assume that both refer to a "homogeneous, smoothly functioning, and well-integrated society made up of a contented and welladjusted people" (Lewis, 1951:428). Ulukhaktok, however, is merely a place that exists because the Hudson's Bay Company (HBC) and the Roman Catholic missionaries favored the protected harbor of King's Bay. Both organizations relocated their regional operations there in the late 1930s.

The King's Bay site was also considered a central point between the ranges of two bands of Copper Eskimos, the Kangiryuarmiut and the Kanghiryuatjagmiut (Jenness, 1922:41), who, broadly speaking, inhabited the regions around Prince Albert Sound and Minto Inlet, respectively. These bands began trading into the new settlement (then called Holman or Holman Island) after the HBC and missionary posts were set up and the $\mathrm{HBC}$ closed operations at Alaervik, in Prince Albert Sound, and at Walker Bay, in Minto Inlet (Condon, 1994). During the 1960s, as Inuit began to settle permanently in Holman, these two groups were also joined by a smaller group of Puivlingmiut - Copper Eskimos who had lived around and traded at the Read Island HBC post, which was closed in 1962 (Usher, 1965:54). While some of the Read Islanders moved to Ulukhaktok, others settled in Coppermine (now Kugluktuk).

In terms of Copper Eskimo heritage, Ulukhaktok's population came from three different, though intermarried, bands that have all settled together. The contemporary Ulukhaktok population also includes a fourth group of people who trace their descent to Mackenzie Delta Eskimos and Alaskan Inupiat groups that began settling at Holman as early as the late 1930s. These people today call themselves Inuvialuit, and, since the ratification of the Inuvialuit Final Agreement in 1984, Ulukhaktok (whose residents voted to join the Inuvialuit land claim) has also been called an Inuvialuit community.

Consequently, the settlement itself is an amalgamation of four different groups of people who all happen to live together in one place. Today, each of these four groups has a highly visible elder recognized as a kind of cultural leader. Invariably, these leaders are the heads of very large families. These groups, sometimes also thought of in a broader sense as "families" locally, do not always get along with each other, and there are numerous, usually subtle, struggles for power and authority at the settlement governance level. These political struggles also manifest themselves in the spiritual realm. In recent years, for example, I have been privy to warnings about elders from rival families who were known to be using angakkok (power) to cause personal misfortune.

On one level, some of these distinctions are seemingly meaningless: these families are all intermarried, and teenage Inuit in Ulukhaktok may have grandparents and greatgrandparents from each of the original bands identified above. Despite these links, however, the distinctions run deep and remain in the community even though casual visitors to the settlement are oblivious to them.

Consequently, a more nuanced approach to understanding community involves examining the activities of individuals within the settlement. What are individuals' motivations? What are individuals' economic strategies in the face of potential threats to stability, such as climate change? Most importantly, to what degree does a settlement's social organization lend itself to the kind of collective action necessary for successfully adapting to change? Essential to this discussion is the notion of what is meant by adaptability in the context of community. A common approach to the topic (outlined by Berkes and Jolly, 2001) is to define "adaptability" as a property of the community, and to use "coping" to refer to individual behavior. Because Ulukhaktok appears to be four different communities, it necessarily makes sense to assess the actions of individual coping strategies - in this case, economic strategiesbefore speculating about adaptability in the larger context in which the term is most commonly used.

\section{Network Analysis}

Social network analysis is both a method and an approach that incorporates anthropologists' and sociologists' long-standing interests in social structure (see, for example, Radcliffe-Brown, 1940; Barnes, 1954; White, 1961; Wasserman and Faust, 1994:9-13; Scott, 2000:7-16). The aim of a network analysis is to uncover the complexities of social systems that emerge from the relationships and interactions between social actors. Understanding who individuals are connected to is a useful lens through which social scientists can explore and comprehend human behavior. Mapping those connections is a means by which we can examine social structures to better focus on individuals and the connections they have with others. In visual terms, symbols for individuals (nodes) are connected by lines (edges) representing ties created by family, friendship, employment, physical proximity, or in the case examined here, food sharing. Important here is the notion that a network approach begins by eliciting the social structure and working toward individual behavior, rather than inferring structure from patterns of individual behavior, which is the approach typically employed by social scientists (Wellman and Berkowitz, 1988). 
The network and structural approaches also attribute data in a different way. That is, in a network analysis, an individual's income, occupation, or educational achievement is a property of his or her relations within a system of agents or collection of individuals or position in a social structure, rather than a property of the individual alone (Scott, 2000:1-5). Networks limit, constrain, or encourage particular kinds of behavior, but they are also measures of social power, influence, and access. As a simple example, individuals with numerous social ties within a particular structure (and who are thus more central to that structure) tend to have greater social and political power because of their social access within that network.

In this paper, I analyze an affiliation network derived from a two-mode matrix. Many network approaches use single-mode data, but I am interested in connections between people and categories of kin. While the affiliation network I examine here is similar to a personal network, it is not the same, because a personal network approach requires interviewing all those nominated by informants as givers or receivers, and this was not possible given the nature of the data collection. Additionally, the network I examine here is unlike most affiliation networks, which tend to focus on events or activities in which multiple individuals might participate; this affiliation network shows connections between individual people, albeit people who have been codified as categories of kin.

Within social network analysis, the analysis of two-mode data is particularly problematic because, as Borgatti and Everett (1997) point out, the data to be considered are relational, and the entities-in this case Inuit informants and kin types - are equally important to the analysis. What is of interest here is how individuals are connected to different kinds of kin, not how kin types are connected via Inuit, nor how Inuit are connected by kin types, although these last two are important to the analysis that will follow. This study is therefore different from standard network analyses both because of the nature of the affiliation (with kinds of people rather than with events and activities) and because of the nature of the data. Whereas most affiliation networks are conducted with an eye toward measuring (as an example) attendance at events or activities, the data here are more behavioral in nature: These are cases in which individuals engaged in specific actions.

In a much broader sense, the affiliations that individuals have with different groups (in this case, different kinds of kin) are fundamental to the formation of an individual's social identity. Affiliations are important because they provide opportunities both to develop interpersonal connections and to demonstrate one's adherence to particular social or cultural values (for a review, see Wasserman and Faust, 1994:292-298). The implication is that affiliation with particular categories of kin can encourage or constrain connections with other individuals and provide particular advantages or disadvantages in the construction of an Inuk's social identity.
The use of country food to mark affiliations is important because food exchange is a culturally salient and easily accessible measure of social relationships. Other currencies could be used to measure social relationships, including exchanges of money or store food, or attendance at meetings, sewing clubs, or church services. However, country food exchange networks are useful precisely because they are markers of interactions that carry cultural meaning. Country food exchanges are also economically important because of the nutritional value of the items exchanged, and they are political, in that individuals who give more are held in higher esteem than those who only receive.

During the research reported here, I did attempt to measure the movement of money and store-bought or industrial food (Duhaime et al., 2002). Money is clearly important for Inuit, and money does change hands between individuals and households. However, Inuit are either unwilling to report gifts of money to others or they simply do not keep track of them. Unwillingness to report money transactions appears when very large sums are involved. Exchanges of large sums nearly always provide assistance to a child (or rarely, a sibling) trying to make a down payment on a snowmobile, boat, or ATV, ostensibly to "get it out of the store." Informants stated that such exchanges are usually not repaid as cash. One noted that he expected a large cash gift to be returned as country food. Smaller exchanges of money are much more common. These gifts are for purchasing of cigarettes, soda, or candy and are usually forgotten as soon as they are made. In interviews about both kinds of money exchanges, informants were very clear: these were limited to the nuclear family, and they usually occurred between parents and children.

Industrial food might also be another currency worth using as a measure of network connections. However, though industrial food is frequently exchanged, its use as an exchange currency was largely limited to large, community-wide functions (such as pot-luck dinners at the community hall) or the customary snacks of bannock, cookies, and other tidbits provided during social visits. For my informants, giving or receiving of any kind of food at large community gatherings was not considered sharing at all, nor did Inuit consider eating with others at such functions to be sharing a meal. At these large gatherings, people invariably arrive and sit with their own nuclear families. Snacks offered during social visits simply do not register as important, and so they are neither remembered nor reported to the anthropologist.

\section{METHODS}

\section{Sampling and Data Collection}

The data considered here were collected between March and November 2007. During this period, I worked with a sample of 14 Inuit males between the ages of 35 and 50. Ten of these informants worked with Condon and me during 
the research reported in Condon et al. (1995), and they were already familiar with the study design and the questions asked. The members of the sample represented different economic strategies commonly pursued in Ulukhaktok. Some informants were full-time wage laborers, while others struggled to find and maintain a steady income. Still others pursued a contemporary variant of "traditional hunter" by combining guiding tourist hunters and part-time or seasonal labor with subsistence hunting. The methods used and the questions asked were nearly identical to those reported in that earlier work.

It is important to note that although the sample is small, it includes nearly half of the males in the community who fall within the age range studied, and that these men were chosen because they represent different economic and subsistence strategies within the community (see Usher and Wenzel, 1987). It is equally important to note that the work with informants was particularly time-consuming and intensive. Because of concern about the accuracy of informants and their recall of food exchanges, informants were engaged much more often than just during the biweekly interviews, which allowed for the use of a technique called "phased assertion" to generate the data (Collings, 2009a). Such engagement was necessary to ensure accuracy and to counteract the tendency to overstate food giving and underestimate food gifts from others.

At the beginning of the research, informants were asked to report on their economic situation. Data on income, equipment, household expenditures, and family situation were recorded. This initial interview was connected to a more intensive interview about food sharing and the informants' personal sharing networks. Informants were asked about the intensity and kinds of sharing relationships they had with others in the settlement, and they were asked to assess the ties between those people with whom they shared directly. The personal network data are not presented here, but they did generate significant ethnographic fodder for understanding how different resources, including country food, money, and industrial food, circulate within the settlement.

Every two weeks, I asked informants a series of questions about their hunting effort, the people with whom they had exchanged country foods, their two most recent meals, their employment, and any changes in income. I recorded the species and rough amounts that changed hands, but I also asked for the donor or recipient's name and kinship relation with the informant. Relationships were reported as both an Inuinnaqtun term (if known) and an English equivalent. Informants' reports of kinship terminology closely matched my own understanding of biological relationships between people in the settlement. In total, individuals reported 327 food transactions during the study period.

\section{Categorization and Coding Issues}

Kinship Categories: Informants were asked to report on their specific kin relationships to people with whom they exchanged food. Why use informant connections between kinship categories? One reason is that Ulukhaktomiut have noted that sharing, and general patterns of integration across the settlement, have changed over time. This pattern was well summed up by an informant in a previous study (JK, age 34, male; Collings, 2001:136):

It must be kind of tough for some people because they can't go out and hunt like they used to, and the community isn't looking after people the way that they should. Years ago the community used to look after itself, but compared to then, people are becoming alienated within their community, and people don't look after old people the way that they should. Like I know my family's pretty close knit and we look after each other, but it's like we take care of our own and that's good enough. It's kind of sad because of the society we live in, but that's the way it is.

Despite these apparent changes to patterns of sharing and settlement integration, behavioral directives based on positions within a kinship structure continue to be important in Ulukhaktok. These directives seem to persist even as Inuinnaqtun use is declining. As an example, seniority within the kindred continues to be important. Individuals are expected to defer to both older siblings and older collateral relatives (Damas, 1975).

Copper Eskimo kinship terminology is much more complex in its specifics than English terminology. Damas (1975; subsequent spellings of kinship terms follow Damas) delves into Central Eskimo kinship terminology in much greater detail, but for the purposes of this paper it is sufficient to note as an example that Copper Eskimo terminology provides five separate terms for uncle-aunt pairings. The matrix and network diagrams that result from including all kin terms are, simply put, a mess. To simplify matters, I have therefore collapsed kinship terms into five categories: nuclear family, in-laws, collaterals, distant collaterals, and elders.

"Nuclear Family" refers to the informant's parents and siblings. "In-laws" refers to the informant's wife's parents and siblings. Together, these two categories correspond closely to the Copper Eskimo concept of ilagiit, but I have kept them separate here for reasons that will be explained below. Interestingly, however, though the meaning of ilagiit in this traditional sense is maintained among many elders in the settlement, informants in the sample cohort, if they knew the word at all, reported a broader meaning of the word as a general gloss for "relatives." Informants generally included collateral relatives into this expanded meaning. "Collaterals" here refers to the five different categories of uncle-aunt pairings and to their children. In English, these were invariably referred to as either "uncle/aunt" or "cousin," respectively.

"Distant Collaterals" is a more nebulous category and noteworthy because, although informants stated that a relationship with these people existed, they did not know the 
Inuinnaq kinship term for that relationship. In each case, however, both my informant and I could specify the genealogical connection. Informants could summarize the relationship as something like, "he's some kind of a cousin. Our grandfathers were brothers." In English, this category effectively includes people that Americans might refer to as "second cousins" or "third cousins" and the cousins of parents-who in Ulukhaktok are often thought of as more distantly related uncles or aunts. "Elders" refers to people who in Ulukhaktok today are called elders in English and ataatacciaq or anaanacciaq - a categorical grandfather or grandmother- in Inuinnaqtun.

Employment Categories: In the sample, I identified three economic strategies that Inuit pursued: full-time employment, part-time employment, and hunting. The category "full-time employed" accounted for six individuals. Most of these men worked a 35-hour week for the municipal government, community corporation, or territorial government. One (identified by the pseudonym "Albert" in the figures that follow) was self-employed. Another worked three separate jobs in the settlement that were the equivalent of a full-time job.

"Seasonal, casual, or part-time employment" (hereafter "part-time employed") formed a second category that included four sample members. During the data collection period, these men were engaged in a combination of seasonal work or casual employment, which included working temporary construction jobs, working part-time for the municipality, or working seasonally for a local mining exploration company. The wife of one Inuk in this category ("David") worked part-time at the Northern Store.

"Hunters," the third category, included four informants. None of these men held jobs during the fieldwork, and instead, they gave a contemporary spin to the idea of traditional subsistence hunter. Their money-generating activities largely revolved around a combination of guiding tourist hunters, producing crafts, and selling furs. Three of these hunters had working wives whose jobs further supplemented family income. Two of these women had part-time jobs, while the third worked full-time at the local school. Hunters also demonstrated a marriage pattern somewhat different from that of Inuit in the other categories. Three hunters married women who were not from the settlement, and the fourth ("Andrew") was himself raised in a different community. Andrew moved to Ulukhaktok in his early twenties, married a local woman, and has remained in Ulukhaktok ever since. By contrast, part-time and full-time employed Inuit were all raised in Ulukhaktok and married women who were themselves raised in the settlement.

It is important to note here that these are strategies for generating money, and they do not necessarily imply hunting success. "Hunters" were clearly committed to hunting, and they were generally successful, but they were not necessarily the most successful. The most productive hunter ("Gary") was a wage worker, as was the fourth most productive hunter (“John").

\section{RESULTS AND DISCUSSION}

\section{Analysis of Food-Sharing Networks}

Figure 1 displays the pattern of giving country food to different categories of kin. This figure and subsequent figures were created using the software program NetDraw (Borgatti, 2002). The diagram shows a two-mode affiliation network in a nonmetric multi-dimensional scaling (MDS) layout, which positions nodes (in this case, individuals and kinship categories) so that more similar nodes are located closer together. A line connecting two nodes indicates a giving tie. As an example, Albert gave food to individuals in both his nuclear family and his wife's nuclear family. He did not give to any other kinds of kin.

In Figure 1, James, Donald, Alan, and Brian are all located closer to collaterals and distant collaterals than to other kinds of relatives. This positioning suggests that these people are affiliated more with kin in these categories than they are with their nuclear family or their in-laws. John, Charlie, Gary, William, Mark, and David are more closely affiliated with their nuclear families. Edward and Albert seem to be more affiliated with their in-laws. Isaac is an isolate, as he gave no food to anyone.

The advantage of the MDS layout is that it allows us to interpret the distances between nodes and to generate some insights about the nature and patterns of food giving. In this case, hunters seem to cluster around people who are effectively outside of the Copper Eskimo notion of the ilagiit (parents and siblings of husband and wife); instead, they are affiliated with what Damas (1975) calls the ilaruhariit, a vague but extensive set of kin outside the bounds of the ilagiit. The full-time employed tend to be more closely affiliated with their nuclear family members.

It is important to remember that this graph is an exploratory tool and means very little in the absence of context. Clearly, the layout points to some oddities. Why is Brian (a part-time worker) affiliated with the hunters? Why is Albert (a full-time worker) more closely affiliated with part-time workers and with his in-laws? Brian is interesting because he produced no food during the course of the fieldwork. He does not own any firearms, nor does he own a snowmobile or ATV. Brian's affiliation with hunters and his collateral relatives stems from his giving of food that he did not hunt. On three occasions during the fieldwork, he received shipments of caribou meat from his sister in Kugluktuk. Brian paid the freight charges and then distributed that meat to others in the settlement.

Albert is equally interesting because he appears to be very unlike the other full-time employed men in the sample. This difference is understandable if we consider that he is self-employed and that parents are the overwhelming target of giving in the nuclear family. Albert's parents, unlike those of the other full-time employed men, did not reside in Ulukhaktok during the fieldwork. Consequently, he is more closely affiliated with his wife's family. 


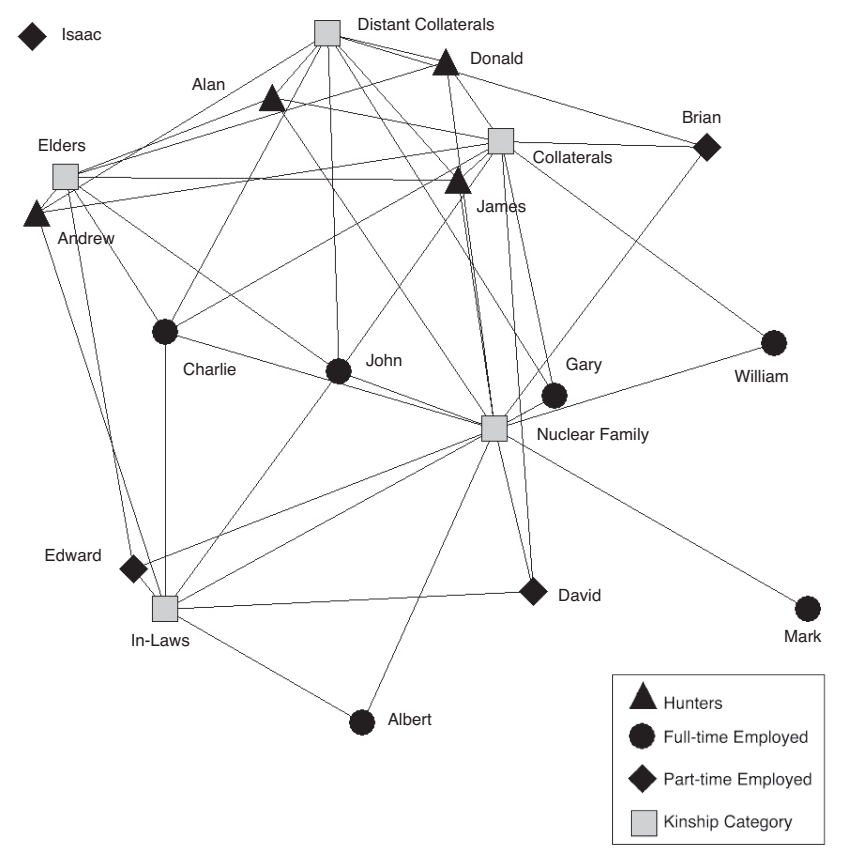

FIG. 1. Food sharing from informants to kinship categories, Ulukhaktok, 2007.

Figure 2 displays the pattern of receiving country food from different categories of kin. What stands out here is that elders gave no food to any members of the sample. Neither Gary nor Donald received food from any kin. This is perhaps not surprising, as they were the top two food producers in the sample. Most informants received food from their nuclear family, primarily from their parents and their parents-in-law. Receiving food from their siblings (or wife's siblings) was much less common. Giving from parents to children is, indeed, the most common pattern in the settlement and has been discussed elsewhere (Condon et al., 1995; Collings et al., 1998; Collings, 2009b).

David, Mark, and Andrew received no food from their parents because they effectively have none: David's father passed away some years ago, and his mother is elderly. Mark's parents are living but elderly. Andrew, as noted earlier, is originally from another community, and his parents did not send him any food.

It is important to remember here that these are records of raw food being given to informants by relatives in the various kinship categories. So, although Gary and Donald received no raw food from their parents (or anyone else), they did receive food from their parents by eating meals together. Indeed, it is common in the settlement for adult children to take at least one meal a day at their parents' house. Gary and Donald differ from the others only in the sense that they never left their parents' house with raw food in a shopping bag.

What truly separates those in the category "hunter," however, is the nature of their food storage. For all members of the sample, it was normative behavior for informants to deposit food with their parents. The customary behavior with this age cohort is for food to be given and stored in the

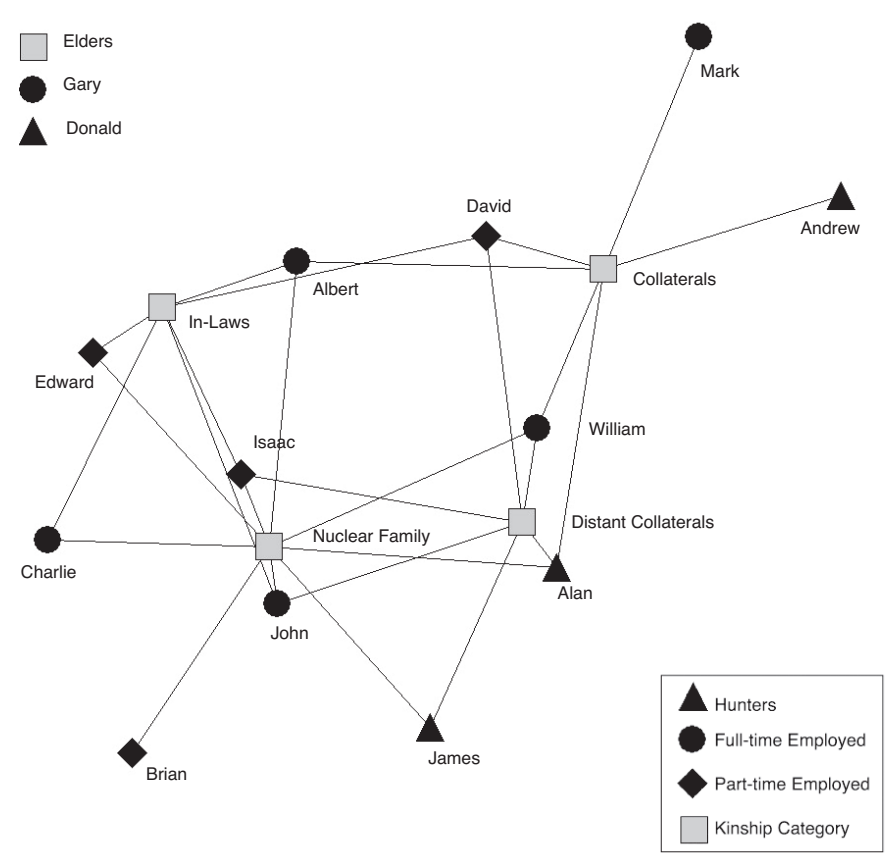

FIG. 2. Food sharing from kinship categories to informants, Ulukhaktok, 2007.

parents' freezer. Usually, the largest share of the food goes to the parents' freezer, and quite often the son retains little if any country food at his own residence. Hunters were different in that, while they too gave much of their catch to their parents, they also maintained freezers of their own. This practice may partly explain why the hunters took so little food from their parents, as each kept a supply in his own household.

Figure 3 combines giving and receiving into a single matrix. What emerges from this diagram is that the categories full-time employed, part-time employed, and hunter seem to be categories with some viability when it comes to sharing. Hunters seem to be alike both in their economic strategy and in the pattern of connections with other kin. Hunters seem to affiliate more with collaterals, distant collaterals, and elders than do other groups. Likewise, full-time and part-time employed Inuit are more closely affiliated with their nuclear families.

\section{Economic Strategies, Food Sharing, and Social Support}

The purpose of this exercise in network analysis is to highlight how different money-generating strategies in Ulukhaktok are associated with different patterns of interaction within the settlement. This kind of detailed investigation of economic strategies and sharing patterns can yield some important insights that simple interviewing, whether in focus groups or semi-structured interviews, cannot accomplish.

Overall, my interpretation of these patterns of food sharing is that sharing patterns are intimately connected to economic strategies. Being employed full-time or being a self-identified hunter has little to do with actual hunting 


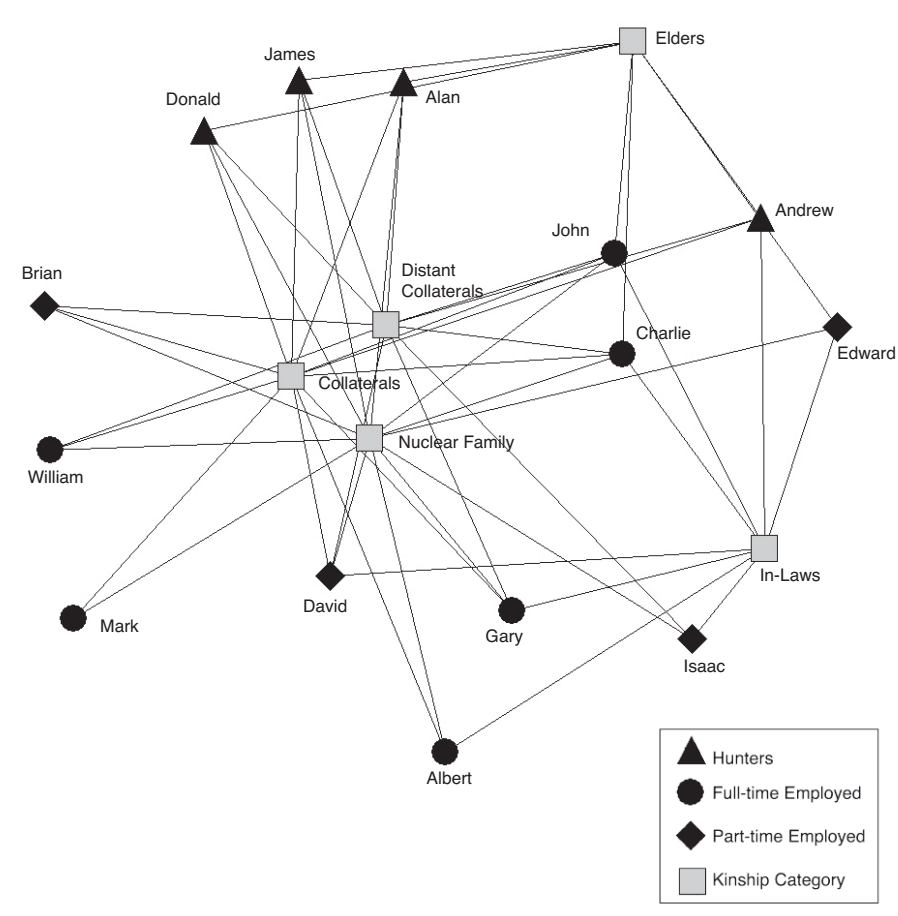

FIG. 3. Food sharing between informants and kinship categories, giving and receiving combined, Ulukhaktok, 2007.

success. Hunters tend to be food producers, but so, too, are some wage laborers. The difference may be in how one goes about producing that food, and the kinds of connections one cultivates to go about it. The data presented here suggest that hunters solve the problems inherent in subsistence much differently than do those who are employed.

Earlier in this paper, I noted that hunters are an interesting group because they engage in a different marriage pattern. This fact alone makes hunters quite different from the other men in the sample: they have one less group of kin upon whom they can rely for assistance. Consequently, these men are at a potential political and economic disadvantage compared to their peers, which may explain why they have cultivated relationships with more distant kin. It may also explain why they are hunters to begin with; perhaps, in the absence of available in-laws, they lack the political influence necessary to acquire and keep a steady, wage-paying job. Perhaps the absence of available in-laws motivates them to focus on producing the food that others receive from their in-laws. Alternatively, perhaps they married outsiders because of a commitment to subsistence that is not attractive to potential spouses who were raised in the settlement.

In any event, it is equally true that hunters tend to solve the problems of subsistence hunting in a very specific way. Despite having some of the highest incomes in the settlement, hunters seemed always to lack cash on hand, and they preferred to solve problems using their social networks. That is, food giving to collaterals and distant collaterals is part of a much more significant movement of goods, involving the free flow of snowmobile and ATV parts, tools, sleds, labor, and other favors, as the following excerpt from field notes indicates:
Donald and Sam (Donald's nephew) were behind Jimmy's place (Jimmy is Donald's father), working on the green Honda. Sam had gone out fishing the day before with friends on the Honda, but he damaged the rear wheel in such a way that the rim, bearing, and axle nut had all been broken.

Donald was trying to hint strongly to Sam that the Honda is only good enough for in town and should stay in town, but Sam countered that Donald's machine is a bigger piece of junk, yet Donald goes on the land with it all the time. What Donald was trying to say was that Sam is the problem: that he drives too fast.

As they were arguing and working on the wheel, though, they could not find the proper bearing to fit the axle: the parts were all slightly different. Robert eventually drove by on his Honda, though. He stopped to see what was going on, and there was an exchange with Donald. Jimmy wanted to know how much Robert wanted for Robert's "other" Honda (a frame with lots of parts but a broken engine); Jimmy and Donald wanted to buy it for parts. Robert did not respond for a while, and then between silence and talking about what was needed to repair the machine, Robert offered that he had a bearing on the old machine and Donald could just have it.

Sam and Robert drove away on Robert's Honda, and about a half hour later they came back with the bearing. Sam and Donald put it back on, Robert watching and smoking a cigarette. When they were finished, Donald said to Robert, "anytime you need parts, just come and take them," waving at an open shack full of engine pieces, and a table (an old cable spool) with tools and parts on it.

This is a typical exchange between hunters. When a hunter needs parts for equipment, he is likely to either make a trip to the dump to forage among the junk machines or ask around to find a replacement part.

An additional benefit to this kind of networking involves the flow of information, which was demonstrated to me as I coped with my own, barely functional, old snowmobile. As I struggled to keep the machine running, Donald and other hunters were quick to provide advice and information about where I might find replacement parts. They often directed me to others who might have knowledge about a specific problem. As I followed some of this advice, it became clear that these connections enabled the acquisition of additional information about weather conditions, the success or failure of other hunters, the locations of animals on the land, or the movement of sea ice.

While this kind of reciprocity occurs among the wage earners as well, it is a much more muted phenomenon. When it comes to parts and equipment, for example, the wage earner's strategy involves using money to solve a problem. Wage earners use cash to purchase new parts or new equipment rather than becoming involved in the reciprocal exchange of parts and tools. One reason for the 
reliance on cash may be time constraints. Men working full-time jobs simply do not have time to go hunting and also forage for parts and equipment, especially when their available time is limited to evenings and weekends. Indeed, several employed informants were well aware of this problem. They noted that it was far easier to purchase parts from the local stores. Additionally, some noted the importance of keeping a supply of spare parts on hand in the event a repair is required and performing as much preventive maintenance of machines and equipment as feasible. Several identified a strategy of purchasing a new snowmobile each year and selling the old one as a way of hedging against breakdowns while on the land.

The problem of time constraints appears not just in the conflict between working time and hunting time. Time spent working also limits the kinds of interactions employed men have with other Inuit. While on the job, their primary contacts are with other wage workers, not with Inuit who are themselves hunting and who have potentially useful information on current conditions, hazards, and the locations of animals. These kinds of network constraints as they relate to information may explain different hunting strategies that seem to emerge among Inuit employing different strategies to generate cash. For example, the most productive hunter in the sample was a wage-earner ("Gary") who focused almost exclusively on hunting muskoxen. In Ulukhaktok, muskoxen can be found relatively close to the settlement, and only minimal knowledge about finding these animals and dealing with potential traveling hazards is required to hunt them successfully. The second most productive wage earner ("John") pursued a different strategy, saving his earnings and vacation time to engage in two expedition hunts during the summer months, when he, his teenage sons, and his mother engaged in two long boating trips to fish and hunt caribou. These two trips produced a large amount of food, accounting for nearly all of his food production during the data collection period. His solution to the problem of information and expertise was to include his mother as a member of the hunting party.

Whether the affiliations determine the strategy or the strategy determines the affiliations is difficult to determine. From the ethnographic evidence, however, my sense is that the strategy of being a hunter requires affiliating with more distant relatives, rather than the other way around. All the men who were hunters strongly expressed the opinion that they wanted to be seen as hunters: that being a hunter was their preferred lifestyle. It seems as if a desire to pursue the strategy, perhaps coupled with a smaller set of close kin, drives an affiliation with more distant kin.

\section{The Problem of Money in Subsistence}

Research on mixed economies in Nunavik (Duhaime et al., 2002; Chabot, 2003, 2004), Baffin Island (Wenzel, 1995), and Alaska (Magdanz et al., 2002; Magdanz and Utermohle, 2005) has paid attention to the way that individual households are situated within broader contexts, often referred to as "multi-household networks" or "superhouseholds" (Wolfe, 1987; Wolfe and Walker, 1987). Likewise, a significant body of work has focused on how money and hunting articulate in Canada (Smith and Wright, 1989; Wenzel, 1991), Alaska (Wolfe and Walker, 1987; Langdon, 1991), and Greenland (Dahl, 1989; Hovelsrud-Broda, 1997, 1999). Most of these studies have demonstrated that significant and important exchanges occur between adult siblings within these structures, so that wage earners who have no time to hunt may engage in direct support of other relatives who lack money but have the time and expertise to hunt. However, Inuit in Ulukhaktok seem to demonstrate a somewhat different pattern, to which I alluded earlier. Money does move between households, but its movement is more restricted than that of food and goods, and individuals do not seem to be directly subsidizing the activities of their siblings.

Several interlocking facets may explain this different pattern. The first may be related to the ways in which Ulukhaktomiut think about money. During the initial interviews, for example, informants indicated that people in Ulukhaktok guard access to their money more than in other settlements. All informants indicated they were cautious about telling their relatives how much money they had at any given time and were loath for others to discover their financial circumstances. At the same time, income and money were not particularly salient variables: some of my informants (among other Inuit in the settlement who were not part of this study) themselves had little idea how much money they had at any given time.

Avoiding declarations about the availability of cash or other resources is something that has been noted elsewhere, particularly by Wenzel (1995), but in Ulukhaktok this pattern seems to have antecedents in Copper Eskimo notions about sharing obligations. Well-provisioned households, regardless of their position within a larger kinship network, are obligated to share their excess (Jenness, 1922:90; Damas, 1972b). In Ulukhaktok, it is common to keep others from knowing how much money one has on hand, for fear of requests to "borrow" money for various real or imagined emergencies. One of my informants ("Charlie") was keenly aware of the problems of direct cash gifts. Charlie's sisterin-law had for a time made repeated requests to borrow money for diapers and food, because her kids were hungry. At first, Charlie and his wife acquiesced and provided cash until they discovered that these cash gifts were instead being used to purchase marijuana and bootlegged alcohol and to bet on poker games. After this discovery, Charlie and his wife resorted to claims that they had no cash, but that they would be happy to take her to the store and charge groceries to their own charge account.

Ulukhaktok might also be different from other locations because Copper Inuit social organization historically lacked the same structure as found among the Netsilik, Iglulik, and Baffin Inuit (see Balikci, 1964; Damas, 1969, 1972a, b; Wenzel, 1995; Collings et al., 1998). The concept of the ilagiit, for example, is much weaker and less 
exclusive among Copper Inuit, and there is a decided lack of the concept of extended family leadership in the form of an ihumataaq (Damas, 1971). Consequently, nuclear-family households have historically been much more autonomous than those found in other parts of the Canadian Arctic, which in turn may explain the apparent absence of the more overt and specific economic linkages between superhouseholds that are found elsewhere.

\section{CONCLUSIONS}

At the beginning of this paper, I noted that much of the current research on climate change and Arctic peoples has focused on the concepts of adaptive capacity and resilience, using the community as the unit of analysis. A community is frequently assumed to be a uniform group of people with similar goals and strategies, but Arctic villages are not necessarily so. In the Canadian Arctic, many settlements were artificially created to meet the needs of the Hudson's Bay Company, Christian missionaries, the Canadian military, or the Royal Canadian Mounted Police. Contemporary settlements may contain people whose histories are quite different from each other.

What are the implications for understanding the human dimensions of climate change? Two intersecting issues are worth exploring. The first revolves around the nature of communities and the concept of adaptability. The second involves understanding the problems of climate change within the broader context of preexisting social, political, and economic forces already at work in Arctic settlements - forces that shape contemporary economic strategies in Ulukhaktok.

If we consider adaptability, the research on climate change in the Arctic to this point has established that Inuit perceive climate change as a threat to both cultural and economic survival. What remains unexplored is how individuals and entire settlements will respond to that perceived threat. The network data examined in this paper suggest that it is now important to focus on the degree to which settlements can adapt to threats - whether perceived or real - to individual livelihoods. The data presented here imply that contemporary economic strategies that are seemingly independent of climate change yield different kinds of interactional patterns between settlement residents. If the ability for a settlement to adapt is predicated upon the ability of a group of people to act collectively, then the fact that contemporary economic trends encourage wage labor and discourage subsistence hunting is troubling. Simply put, wage employment seems to foster the isolation of individuals within the settlement, at least as measured by the movement of country food. "It's like we take care of our own and that's good enough," as JK was quoted earlier in this paper. It is this increasing trend toward isolation that may hamper the ability of Inuit to survive and adapt to the perceived and predicted threats of ongoing and future climate change.
Different strategies likewise may have different vulnerabilities to changing circumstances. Hunters, who depend on tourist hunting for a significant portion of their income, appear to be vulnerable to economic and political changes that threaten the viability of tourist hunting. Indeed, hunters were well aware of this vulnerability, watching the news for reports about whether the U.S. Congress would declare the polar bear endangered and effectively eliminate U.S. citizens as potential clients.

Wage earners, on the other hand, seem to be socially vulnerable. That is, while their access to cash appears to be reasonably stable, their ability to engage in the subsistence economy seems to be vulnerable to social and ecological perturbations. In a network that is more focused on nuclear family connections, the death of a parent could have greater consequences for access to country food. A limited network also might limit the kind and quality of available information pertaining to changing environmental conditions.

The perceived and real threats of climate change to Arctic peoples do not exist as unique or isolated stressors, as has been duly noted previously (Nuttall, 2004; Ford et al., 2006a; Wenzel, 2009). The present paper has argued that climate change, though a topic at the forefront of Arctic politics and policy, is but one of many challenges to which people in Arctic villages must adapt. The economic strategies that Inuit pursue today, for example, are the result of a process of social, economic, and political changes that Inuit in Ulukhaktok have endured for almost a century, from the pre-contact lifestyle of these informants' grandparents, to the contact-traditional lifestyle of their parents, to their own current lifestyle. It seems that on one level an economic strategy focusing on subsistence hunting at the expense of wage labor might provide the flexibility to adapt to changing ecological circumstances, such as those presented by climate change. Despite the potential advantage of being a hunter, however, external political forces may effectively prevent many Inuit from pursuing such a strategy.

In conclusion, this paper has examined some of the issues central to climate change from the perspective of what people do in the context of a changing climate, rather than what they say about it. The examination of contemporary economic strategies and the food networks that flow from them suggests that these different strategies have implications for a settlement's ability to adapt to threats posed by a rapidly changing climate. However, these threats, as Wenzel (2009) notes, may not come from the predicted and observed changes in wildlife availability or increasing hazards associated with subsistence hunting, but rather from the political dimensions of climate change that are external to both Inuit society and the environment in which Inuit live. Perhaps ironically, it seems that the greatest potential for assuaging the effects of climate change may be found in an economic and social strategy that is more closely based on traditional notions of subsistence and social structure. 


\section{ACKNOWLEDGEMENTS}

This research was supported by a grant from the National Science Foundation, Office of Polar Programs (Award number ARC0615251). Additionally, I would like to thank George Wenzel, Alyson Young, Lance Gravlee, and three anonymous reviewers for comments on earlier drafts of this paper. Most importantly, this research would be impossible without the support of the people of Ulukhaktok, who have kindly and graciously tolerated my presence and strange questions. Special thanks go to Jerry Akoakhion, Adam Kudlak, Jack Kataoyak, Morris Nigiyok, and Harold Wright for assistance and guidance during the course of the research.

\section{REFERENCES}

Balikci, A. 1964. Development of basic socioeconomic units in two Eskimo communities. Ottawa: National Museum of Canada Bulletin 202.

Barnes, J.A. 1954. Class and committees in a Norwegian Island parish. Human Relations 7:39-58.

Berkes, F., and Jolly, D. 2001. Adapting to climate change: Socialecological resilience in a Canadian western Arctic economy. Conservation Ecology 5(2):18, http:/www.consecol.org/vol5/ iss $2 /$ art18/.

Berkes, F., Colding, J., and Folke, C., eds. 2003. Navigating social-ecological systems: Building resilience for complexity and change. Cambridge: Cambridge University Press.

Berman, M., and Kofinas, G.P. 2004. Hunting for models: Grounded and rational choice approaches to analyzing climate effects on subsistence hunting in an Arctic community. Ecological Economics 49:31-46.

Berman, M., Nicolson, C., Kofinas, G., Tetlichi, J., and Martin, S. 2004. Adaptation and sustainability in a small Arctic community: Results of an agent-based simulation model. Arctic 57:401-414.

Borgatti, S.P. 2002. NetDraw network visualization. Harvard, Massachusetts: Analytic Technologies.

Borgatti, S.P., and Everett, M.G. 1997. Network analysis of 2-mode data. Social Networks 19:243-269.

Brinkman, T.J., Kofinas, G.P., Chapin, F.S., III, and Person, D.K. 2007. Influence of hunter adaptability on resilience of subsistence hunting systems. Journal of Ecological Anthropology 11:58-65.

Chabot, M. 2003. Economic changes, household strategies, and social relations of contemporary Nunavik Inuit. Polar Record 39:19-34.

2004. Consumption and standards of living of the Quebec Inuit: Cultural permanence and discontinuities. Canadian Review of Sociology and Anthropology 41:147-170.

Cohen, S.J. 1997. What if and so what in northwest Canada: Could climate change make a difference to the future of the Mackenzie Basin? Arctic 50:293-307.

Collignon, B. 2006. Inuit place names and sense of place. In: Stern, P., and Stevenson, L., eds. Critical Inuit studies: An anthology of contemporary Arctic ethnography. Lincoln: University of Nebraska Press. 187-205.
Collings, P. 1997. Subsistence hunting and wildlife management in the Central Canadian Arctic. Arctic Anthropology 34(1): $41-56$.

. 2000. Aging and life course development in an Inuit community. Arctic Anthropology 37(2):111-125.

— 2001. 'If you got everything, it's good enough': Perspectives on successful aging in a Canadian Inuit community. Journal of Cross-Cultural Gerontology 16:127-155.

- 2005. Housing policy, aging, and life course construction in a Canadian Inuit Community. Arctic Anthropology 42(2):50-65.

- 2009a. Participant observation and phased assertion as research strategies in the Canadian Arctic. Field Methods $21: 133-153$.

- 2009b. Birth order, age, and hunting success in the Canadian Arctic. Human Nature 20:354-374.

Collings, P., Wenzel, G., and Condon, R.G. 1998. Modern food sharing networks and community integration in the Central Canadian Arctic. Arctic 51:301-314.

Condon, R.G. 1987. Inuit youth: Growth and change in the Canadian Arctic. New Brunswick, New Jersey: Rutgers University Press.

- 1988. Inuit youth in a changing world. Cultural Survival Quarterly 12.2. http://www.culturalsurvival.org/ ourpublications/csq/article/inuit-youth-a-changing-world.

- 1990a. Adolescence and changing family relations in the Central Canadian Arctic. Arctic Medical Research 49:81-92.

- 1990b. The rise of adolescence: Social change and life stage dilemmas in the Central Canadian Arctic. Human Organization 49:266-279.

- 1991. Birth seasonality, photoperiod, and social change in the Central Canadian Arctic. Human Ecology 19:287-321.

- 1992. Changing patterns of conflict management and aggression among Inuit youth in the Canadian Arctic: Longitudinal ethnographic observations. Native Studies Review 8:35-49.

- 1994. East meets West: Fort Collinson, the fur trade, and the economic acculturation of the Northern Copper Inuit, 1928-1939. Études/Inuit/Studies 18:109-135.

Condon, R.G., Collings, P., and Wenzel, G. 1995. The best part of life: Subsistence hunting, ethnicity, and economic adaptation among young adult Inuit males. Arctic 48:31-46.

Crate, S. 2008. Gone the bull of winter? Grappling with the cultural implications of and anthropology's role(s) in global climate change. Current Anthropology 49:569-595.

Dahl, J. 1989. The integrative and cultural role of hunting and subsistence in Greenland. Études/Inuit/Studies 13:23-42.

Damas, D. 1969. Environment, history, and Central Eskimo society. National Museum of Canada Bulletin 230, Contributions to Anthropology, Ecological Essays. 40-64.

- 1971. The problem of the Eskimo family. In: Ishwaran, K., ed. The Canadian family: A book of readings. Toronto: Holt, Reinhart, and Winston of Canada. 54-78.

.1972a. Central Eskimo systems of food sharing. Ethnology 11:220-240. 
1972b. The structure of Central Eskimo associations. In: Guemple, D.L., ed. Alliance in Eskimo society. Seattle: University of Washington Press. 40-55.

- 1975. Three kinship systems from the Central Arctic. Arctic Anthropology 12(1):10-30.

Duhaime, G., Chabot, M., and Gaudreault, M. 2002. Food consumption patterns and socioeconomic factors among the Inuit of Nunavik. Ecology of Food and Nutrition 41:91-118.

Ford, J.D., and Smit, B. 2004. A framework for assessing the vulnerability of communities in the Canadian Arctic to risks associated with climate change. Arctic 57:389-400.

Ford, J.D., Smit, B., Wandel, J., and MacDonald, J. 2006 a. Vulnerability to climate change in Igloolik, Nunavut: What we can learn from the past and present. Polar Record 42: $127-138$.

Ford, J.D., Smit, B., and Wandel, J. 2006b. Vulnerability to climate change in the Arctic: A case study from Arctic Bay, Canada. Global Environmental Change 16:145-160.

Ford, J.D., Pearce, T., Gilligan, J., Smit, B., and Oakes, J. 2008. Climate change and hazards associated with ice use in northern Canada. Arctic, Antarctic, and Alpine Research 40: $647-659$.

Fox, S. 2002. These are things that are really happening: Inuit perspectives on the evidence and impacts of climate change in Nunavut. In: Krupnik, I., and Jolly, D., eds. The earth is faster now: Indigenous observations of Arctic environmental change. Fairbanks: Arctic Research Consortium of the United States. 12-53.

Furgal, C.M., and Seguin, J. 2006. Climate change, health, and vulnerability in Canadian northern aboriginal communities. Environmental Health Perspectives 114:1964-1970.

Gunderson, L.H. 2000. Ecological resilience - In theory and application. Annual Review of Ecology and Systematics 31:425-439.

- 2002. Adaptive dancing: Interactions between social resilience and ecological crises. In: Berkes, F., Colding, J., and Folke, C., eds. Navigating social-ecological systems: Building resilience for complexity and change. Cambridge: Cambridge University Press. 33-51.

Gunderson, L.H., and Holling, C.S., eds. 2002. Panarchy: Understanding transformations in human and natural systems. Washington, D.C.: Island Press.

Gunderson, L.H., Holling, C.S., and Light, S.S., eds. 1995. Barriers and bridges to the renewal of ecosystems and institutions. New York: Columbia University Press.

Hovelsrud-Broda, G. 1997. Arctic seal-hunting households and the anti-sealing controversy. Research in Economic Anthropology 18:17-34.

- 1999. The integrative role of seals in an east Greenlandic hunting village. Arctic Anthropology 36(1-2):37-50.

Huntington, H.P., and Fox, S. 2005. The changing Arctic: Indigenous perspectives. Chapter 3 in Arctic climate impact assessment: Scientific report. Cambridge: Cambridge University Press. 62-98.

Jenness, D. 1922. The life of the Copper Eskimos. Report of the Canadian Arctic Expedition, 1913-1918, Vol. 12. Ottawa: F.A. Acland.
Jolly, D., Berkes, F., Castleden, J., Nichols, T., and the Community of Sachs Harbour. 2002. We can't predict the weather like we used to: Inuvialuit observations of climate change, Sachs Harbour, Western Canadian Arctic. In: Krupnik, I., and Jolly, D., eds. The earth is faster now: Indigenous observations of Arctic environmental change. Fairbanks: Arctic Research Consortium of the United States. 92-125.

Kelly, P.M., and Adger, W.N. 2000. Theory and practice in assessing vulnerability to climate change and facilitating adaptation. Climatic Change 47:325-352.

Krupnik, I., and Jolly, D., eds. 2002. The earth is faster now: Indigenous observations of Arctic environmental change. Fairbanks: Arctic Research Consortium of the United States in cooperation with the Arctic Studies Center, Smithsonian Institution.

Langdon, S.J. 1991. The integration of cash and subsistence in Southwest Alaskan Yup'ik Eskimo traditions. In: Peterson, N., and Matsuyama, T., eds. Cash, commoditisation and changing foragers. Osaka: National Museum of Ethnology. 269-291.

Lewis, O. 1951. Life in a Mexican village: Tepoztlan restudied. Urbana: University of Illinois Press.

Magdanz, J., and Utermohle, C.J. 2005. Social networks and wildlife management: An example from Deering, Alaska. Paper presented at the 2005 Alaska Anthropological Association Conference, Anchorage, Alaska, March 2005.

Magdanz, J., Utermohle, C.J., and Wolfe, R.J. 2002. The production and distribution of wild food in Wales and Deering, Alaska. Technical Paper 259. Juneau: Division of Subsistence, Alaska Department of Fish and Game.

McCarthy, J.J., and Martello, M.L. 2005. Climate change in the context of multiple stressors and resilience. Chapter 17 in Arctic climate impact assessment: Scientific report. Cambridge: Cambridge University Press. 945-988.

Nuttall, M. 2005. Hunting, herding, fishing, and gathering: Indigenous peoples and renewable resource use in the Arctic. Chapter 12 in Arctic climate impact assessment: Scientific report. Cambridge: Cambridge University Press. 649-690.

Pearce, T.D., Smit, B., Duerden, F., Kataoyak, F., Goose, A., Inuktalik, R., Ford, J., and Wandel, J. 2006. Travel routes, harvesting, and climate change in Ulukhaktok, Canada. Paper presented at the Fourth Northern Research Forum, 5-8 October, Oulu and Tornio, Finland, and Haparnada and Lulea, Sweden.

Pearce, T.D., Ford, J.D., Laidler, G.J., Smit, B., Duerden, F., Allarut, M., Andrachuk, M., et al. 2009. Community collaboration and climate change research in the Canadian Arctic. Polar Research 28:10-27.

Pearce, T., Smit, B., Duerden, F., Ford, J., Goose, A., and Kataoyak, F. 2010. Inuit vulnerability and adaptive capacity to climate change in Ulukhaktok, Northwest Territories, Canada. Polar Record 46:157-177.

Peterson, D.L., and Johnson, D.R., eds. 1995. Human ecology and climate change: People and resources in the Far North. Washington: Taylor and Francis.

Radcliffe-Brown, A.R. 1940. On social structure. Journal of the Royal Anthropological Institute of Great Britain and Ireland $70: 1-12$. 
Riedlinger, D., and Berkes, F. 2001. Contributions of traditional knowledge to understanding climate change in the Canadian Arctic. Polar Record 37:315-328.

Robards, M., and Alessa, L. 2004. Timescapes of community resilience and vulnerability in the circumpolar North. Arctic $57: 415-427$.

Scott, J. 2000. Social network analysis: A handbook, $2^{\text {nd }}$ ed. Los Angeles: Sage Publications.

Smit, B., and Wandel, J. 2006. Adaptation, adaptive capacity, and vulnerability. Global Environmental Change 16:282-292.

Smith, T.G., and Wright, H. 1989. Economic status and role of hunters in a modern Inuit village. Polar Record 25:93-98.

Stirling, I., and Smith, T.G. 2004. Implications of warm temperatures and an unusual rain event for the survival of ringed seals on the coast of southeastern Baffin Island. Arctic 57:59-67.

Tremblay, M., Furgal, C.M., Lafortune, V., Larrivee, C., Savard, J., Barrett, M., Annanack, T., et al. 2006. Communities and ice: Linking traditional and scientific knowledge. In: Riewe, R., and Oakes, J., eds. Climate change: Linking traditional and scientific knowledge. Winnipeg: Aboriginal Issues Press, University of Manitoba. 123-138.

Ulijaszek, S.J. 1997. Human adaptation and adaptability. In: Ulijaszek, S.J., and Huss-Ashmore, R.A., eds. Human adaptability: Past, present, and future. New York: Oxford University Press. 7-16.

Usher, P.J. 1965. Economic basis and resource use of the Coppermine-Holman Region, N.W.T. (NCRC-65-2). Ottawa: Department of Northern Affairs and National Resources, Northern Co-ordination and Research Centre.

Usher, P.J., and Wenzel, G. 1987. Native harvest surveys and statistics: A critique of their construction and use. Arctic 40:145-160.
Wasserman, S., and Faust, K. 1994. Social network analysis: Methods and applications. Cambridge: Cambridge University Press.

Wellman, B., and Berkowitz, S.D. 1988. Introduction: Studying social structures. In: Wellman, B., and Berkowitz, S.D., eds. Social structures: A network approach. Cambridge: Cambridge University Press. 1-14.

Wenzel, G. 1991. Animal rights, human rights: Ecology, economy, and ideology in the Canadian Arctic. Toronto: University of Toronto Press.

- 1995. Ningiqtuq: Resource sharing and generalized reciprocity in Clyde River, Nunavut. Arctic Anthropology 32(2):43-60.

. 2008. Clyde Inuit settlement and community: From before Boas to centralization. Arctic Anthropology 45(1):1-21.

- 2009. Canadian Inuit subsistence and ecological instability-If the climate changes, must the Inuit? Polar Research 28:89-99.

White, H.C. 1961. Management conflict and sociometric structure. American Journal of Sociology 67:185-199.

Whiting, A. 2002. Documenting Qikiktagrugmiut knowledge of environmental change. Kotzebue: Native Village of Kotzebue, Alaska.

Wolfe, R.J. 1987. The super-household: Specialization in subsistence economies. Paper presented at the 14th Annual Meeting of the Alaska Anthropological Association, 12-13 March 1987.

Wolfe, R.J., and Walker, R. 1987. Subsistence economies in Alaska: Productivity, geography, and development impacts. Arctic Anthropology 24(2):56-81. 